\title{
ホログラフィー干渉計を用いる高速現象の可視化*
}

高山 和喜**

\section{Visualization of High-Speed Phenomena Using Holographic Interferometry}

\author{
Kazuyoshi TaKaYAma
}

\section{1. 緒論}

「百聞は一見に如かず」と言うように，流れの可視化 写真から, 離散点での圧力や温度の時間変化の測定に比 ベ，ある瞬間の流れ場全体を容易に理解することができ る. 高速流れは密度変化を伴うので, その可視化には影 写真法やシュリーレン法がある.これらの方法は, 19 世紀にレンズの磨き精度を検定する手段として開発され た. 影写真では流れ密度変化の勾配を検出できる. Toepler は影写真のフィルム側の焦点位置にナイフェッジ を挿入して，流れの密度勾配を検出する方法を提唱し， 現在のシュリーレン法の基礎を築いた．彼はその方法を 使って，放電でできた球状衝撃波が壁から反射する様子 を観察して，結果のスケッチを 1867 年のパリ万国博覧 会に出展した。これは衝撃波研究の歴史で最初の可視化 である。しかし，そのスケッチには，残念なことに，壁 で反射した衝撃波が現在マッハ反射と呼ばれる形態に変 化する部分が修正されていたので，もし，Toepler が衝 撃波の反射を見た通りにスケッチしていたら，彼は衝撃 波研究の先駆者と呼ばれたはずで1)，科学史に名を残す と言う名誉を逸し，単にシュリーレン法の発明者となっ た。

1875 年, E. Mach は息子の Ludwig と協力して, ジャ マン干涉計を改良して Mach-Zehnder 干涉計を発明し， この装置で流れの密度が定量的に計測できるようになっ た2).

1949 年, Gabor ${ }^{3)}$ は電子顕微鏡の解像度を高める研究 で，位相の揃った単色光で現象を照射し，記録したフィ ルムに再びこの光を当てれば，現象の位相情報を再生で きる原理を発見した。これは後にホログラフィー (Holography）と呼ばれ，Gaborはこの発明で 1971 年ノーべ ル物理学賞を受賞している. 現在, 高性能のパルスレー ザーが市販されるようになって，ホログラフィー法は流 れの可視化の有力な手段となっている.ここでは, 衝撃 波や高速流れをホログラフィー法で計測することの利点 を述べ，フーリエ縞解析で定量的な流れ計測を試みた例

* 原稿受付 1999 年 7 月 1 日

** 正会員 東北大学 流体科学研究所 衝撃波研究センター
を示す。

\section{2. 二重露光ホログラフィー干渉計}

光は電磁波なので, 波形は振幅，波長と位相で決定さ れ, 波長は光の色，振幅は光の強度，位相は波形の正弦 波からのずれを表わす。フィルムは被写体を通過あるい は反射した光の振幅情報のみを記録し，フィルム上の濃 淡は被写体から発する光の振幅情報の空間分布を示し， 位相情報は記録できない. Gabor は光源の光を物体光と 参照光として，フィルム上に重ね合わせて露光し，一旦， 被写体の像を振幅情報として記録し，このフィルムを参 照光で照射すると，振幅情報を示す濃淡分布は参照光に 対して回折格子として働いて，被写体の位相情報が虚像 あるいは実像となって再生されることを示した。これは ホログラフィーの原理である．ホログラフィー（holog raphy）とは「全てを見る」という意味の期待を込めた 造語である. Gabor のホログラフィー法は単純なもので あったが，レーザー光が普及するにつれて様々のホログ ラフィー法が提唱され，現在，可視化技術に重要な位置 を占めている.

Gaborのホログラフィー法は物体光と参照光が同じ光 軸上を通るので, イン・ライン・ホログラフィー (in-line holography）と呼ばれる。一方，物体光と参照光は異 なる光路を経てフィルム上にある角度で交差して重ねて 露光される方法はオフ・アクシス・ホログラフィー (off -axis holography) と呼ばれる.イン・ライン・ホログ ラフィー法は，現在，微粒子の計測など比較的限られた 目的に応用されている，一方，後者は光学系の空間配置 が比較的自由なので, 変位計測, 温度や密度変化の計測 など広く応用されている．また，ホログラフィー法で三 次元的な被写体を立体的に表示する写真芸術の分野が開 拓され，その撮影には後者が用いられている。

1961 年, Leith と Upatnieks ${ }^{4)}$ はフ・アクシス・ホ ログラフィーで, 被写体の現象が現れる前に一回目の撮 影を行い現象に同期させて二回目の露光を行い，この二 重露光の間に現れた被写体の変位あるいは密度変化を記 録する技法を提唱した。これは二重露光ホログラフィー 干涉計法 (double exposure holographic interferometry) 
と呼ばれている. 二回の露光の間に現れる現象の位相情 報の変化を位相角の変化 $\Delta \phi$ とすれば, 再生された干涉 計写真に現れる縞の強度分布 $I$ は,

\section{$I \cos \Delta \phi$,}

で表され，位相角が $\pi$ 変化する毎に, 濃淡の干渉縞が 現れる.また，二次元の衝撃波管流れを考えれば，位相 角は干涉縞の次数 $N$ で変化し, 密度変化 $\Delta \rho$ に対応し て次式のように表される。

$$
\Delta \rho=2 \pi L k N / \lambda,
$$

ここに，L は衝撃波管の測定部の幅， $k$ は GladstoneDale 定数，入はレーザー光の波長である. (2)式より縞次 数分布は密度分布に対応する.

\section{1 衝撃波管実験の光学系}

Fig. 1 は東北大学流体科学研究所衝撃波研究センター の二重露光ホログラフィー干渉計法の光学系を示す5). 光源は $\mathrm{TEM}_{00}$ モードの二重露光パルスルビーレーザー,

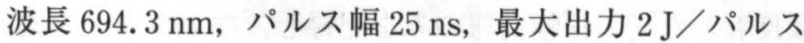
である. 光源の光は, ビーム・スプリッター (beam splitter, BS）で被写体を照射する物体光（object beam, OB） と基準となる光源の光, 参照光 (reference beam, PB) に分離される.

物体光は影写真光学系と同じで, OB は凹レンズで拡 大光となって放物面鏡, 直径 $300 \mathrm{~mm}$, 焦点距離 $3 \mathrm{~m}$ で 反射して平行光線となり測定部を通過する．測定部を通 過した平行光線は光源側の放物面鏡と同じ特性の放物面 鏡で反射し収束する．その焦点位置近傍に結像レンズを 挿入して測定部の被写体の像をフィルム面に結像させる 一般に, ホログラフィー法では物体光は散乱光で被写体 を照射するので，結像レンズを使わない.ここに用いる ホログラフィー法はイメージ・ホログラフィー (image holography）とも呼ばれる. ホログラフィーフィルム は $100 \mathrm{~mm} \times 125$ mmAGFA 10 E 75 シートフィルムで, フィルムホールダー (film holder, FH) 上に固定される。 $\mathrm{FH}$ ではアルミニウム製の滑らかに仕上げた平面に直径 約 $1 \mathrm{~mm}$ の孔が約 $10 \mathrm{~mm}$ 間隔に分布している.この孔

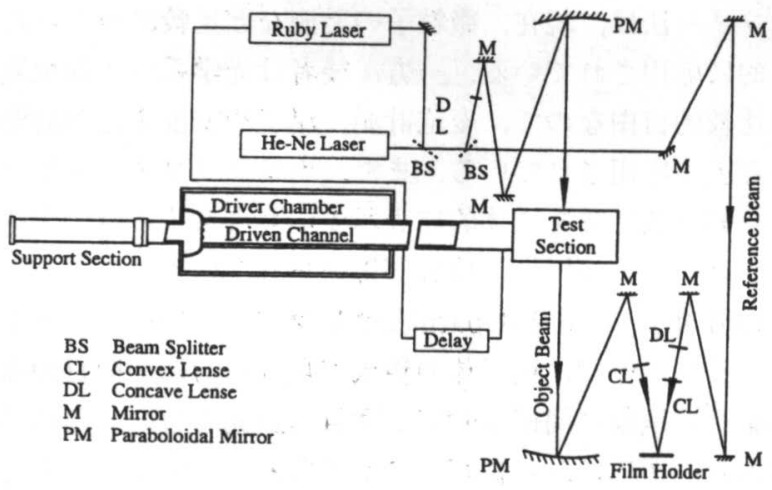

Fig. 1 Holographic Interferometric Optical Arrangement for Shock Tube Experiment
はアルミ平面背後の低圧の空間につながっているので, 面上のフィルムは大気圧との差圧で $\mathrm{FH}$ 上に吸着されて 固定される. 現在，このシートフィルムは製造が中止さ れていて低感度の代換え品があるが，その特性はシート フィルムには劣るようである.

一回目の露光は現象の前に, 二回目の露光は現象に同 期して行われる.レーザーの制御回路で二回の露光間隔 を任意に設定できるので，第一回目の露光で現象に同期 させる．参照光は BS を通過後，平面鏡で反射を繰り返 し物体光とほとんど同じ光路長を経て, Fig. 1 に示すよ うに $\mathrm{RB}$ を直径 $200 \mathrm{~mm}$ の凸レンズで拡大し, 平行光線 として $\mathrm{FH}$ 上のフィルムに $\mathrm{OB}$ と重ねて露光する. もし 二回露光間に $R B$ の光路が変わらなければ, 得られる写 真の干渉縞は等密度線に対応し，これを無限干渉縞写真 (infinite fringe interferogram) と呼ぶ. 一方, 二回の 露光のいずれかで，この凸レンズを光軸に垂直に保って 中心をずらして二重露光撮影すると, 干渉写真には中心 のずれた距離に見合った平行で一様に傾いた干渉縞が現 れる.これを有限干渉縞写真 (finite fringe interfrogram) と呼ぶ. また，有限干涉縞の傾き方向は凸レンズの中心 が移動する方向を変えて制御する.

Fig. 2 にこの凸レンズを示す ${ }^{6)}$. レンズの取り付け枠 は一点で支持され，支持点を中心に振れる構造をもち， その変位量はマイクロメーターで設定できる.さらにレ ンズの取り付け枠を回転させてレンズを振る方向を選択 できる，なお，二回露光の間にレンズの移動を手動で操 作するときには, レーザーの内部トリガーでの二重露光 ではなくて，一回露光を独立に二度繰り返し，この間に レンズの中心を移動させる.

イメージ・ホログラムは現象の密度変化を影写真と同 じ光学系で記録する.アルゴンイオンレーザー光を平行 光線にして，このホログラムを照射すると光源と反対側 に被写体の実像が現れるので，この像を凸レンズで結像 してネオパン ss 級シートフィルム $100 \mathrm{~mm} \times 125 \mathrm{~mm} に$ 記録する。

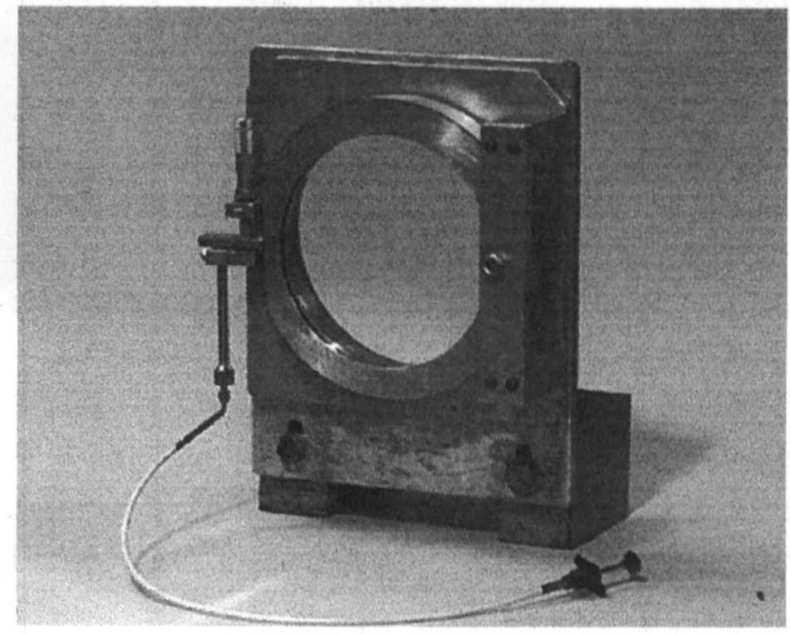

Fig. 2 A Convex Lens for Collimating RB 
物体光を散乱光にして被写体を照射し反射散乱光をホ ロフィルムに直接露光すると; 再生過程では光源側に被 写体の虚像が現れる.この像は三次元的であるが, イメー ジ・ホログラムに比べ画像の空間解像が劣る。基本的な 光学系は, Fig. 1 の光学系で結像レンズを取り除き,フィ ルムを測定部に対面する位置に近づけ，また，测定部の 光源側に物体光を拡散させる散乱体を挿入した配置にな る.

\section{2 フーリエ縞解析}

有限綂干涉計写真の縞分布をフーリエ解析して密度分 布を求める7フーリエ縞解析法は現在広く用いられてい る画像解析法で, ここに示す方法は, 本センターの Babinsky 助手がケンブリッジ大学に転出する前に手掛け, オーストラリア国立大学の Russell 博士が整備し, 最近, 同大学の Houwing 教授が本センターに客員教授として 滞在中に完成した国際共同研究の成果である ${ }^{8)}$.

その手順は：2.1節で示した有限稿干涉計写真をトリ ミングして引き伸ばし，その画像をイメージ・スキャ ナーでワークステーション上に取り込む；取り込んだ干 涉縞の濃淡をある直線の検查線に沿って切断し，線上の 干涉縞情報をコンピューター上でフーリエ変換する； フーリエ変換した情報を正規化してフーリエ変換面を作 り周波数分布で表示する;検査線を走引して画面全体を フーリエ変換する; 得られたフーリエ変換の周波数分布 から，ホログラムを作るときに現れた衝撃波現象に無関 係の低周波と高周波雑音成分を取り除く；その結果に二 次元のフーリエ逆変換を施して, 二次元の位相角分布を 求め，(2)式で見たように密度分布を求めることができる 誤差の原因は干渉縞の読みとり精度が主なもので，縞 の間隔と方向が密度変化の向きと直交するように工夫す ることが必要である．また，低周波と高周波成分を除去 する過程で系統的な誤差が導入されるが，系統的な誤差 は 15\%以下である．位相角分布が求まれば，(1)式の関 係から縞次数は決まり，(2)式から密度分布を求められる ことになる。

現在マニュアルが整備されて一般的な利用もできるが, 処理過程を完全に自動化することはやや難しい. 求めら れる位相角は常に0から $2 \pi$ の間で変化するので, 隣り 合う位相角の変化が単調増大か減少かを判断するには, 衝撃波と流れを見抜く経験も必要であるが，数值解を援 用したりシュリーレン法の濃淡分布やカラーシュリーレ ン法の色分布から推定することも考えられる. 計測の実 例を後に示す。

\section{3 ．気体中の高速現象への応用}

Wortberg ら², Russell ら!0) はホログラフィー干渉計 法を衝撃波管の実験に応用し第 11 回国際衝撃波管シン ポジウムで報告している.しかし, 初期のホログラフィー 干涉計法の画像はマッハ・ッェンダー干渉計の写真に比 ベてノイズが多く，また，画像の空間解像も見劣りした。
東北大学流体科学研究所では, 1975 年, 衝撃波の多目 的利用を視野に二重露光ホログラフィー干涉計法の応用 を開始した，最初の成果を 1983 年に公表し，水中衝撃 波の観察に特段の威力があることを示した, Takayama". その後, 技術の習得と改良の結果, 1985 年, 気体中の 衝撃波現象に対してもこの可視化法がマッハ・ツェン ダー干涉計に劣らない特性を発揮することを確信した。

\section{1 衝撃波のマッハ反射}

空気力学の教科書には，斜め衝撃波の反射には正常反 射と呼ばれる形態があって，この形態では与えられた衝 撃波マッ八数に対して，入射角を変化させれば反射角は その值に対応して一意的に求められるが, 反射角が定ま らなくなる入射角からマッハ反射と呼ばれる形態が出現 すると記述されている，マッ八反射は，衝撃波の非線形 性を代表する特性で, 正常反射に対応しない反射形態を マッハ反射とする解釈は，「マッハ反射とは何か」とい う本質的な疑問に答えていない" ${ }^{11}$.

与えられた気体とマッハ数に対して，反射衝撃波の形 態が正常反射からマッハ反射に変わる遷移臨界角を解析 的に求める研究は衝撃波の動力学の重要な研究課題と なっている. しかし, 知られている解析結果は, 古くか ら衝撃波管実験の結果と食い違うばかりでなく衝撃波管 の大きさや実験条件でも異なることが知られている ${ }^{11}$. さらに, 弱い衝撃波のマッハ反射では解析解は実験結果 と全く異なり，この事実はフォンノイマン・パラドック スと呼ばれている.

定量的な光学可視化法を駆使して,この理論之実験と の食い違いを明らかにすることは衝撃波の動力学の永続 的な研究課題となっている。そそのため可視化結果と精緻 な数值解との対比が重要で, 最近の衝撃波管の可視化で は，単に衝撃波が写うているという段階を越えた画像の 空間解像度が要求されている. 東北大学流体科学研究所 衝撃波研究センターでは, $100 \mathrm{~mm} \times 180 \mathrm{~mm}$ 衝撃波管 に急速開口弁を用いて無隔膜衝撃波管とし，その再現性 を向上させ空気中で衝撃波マッハ数 1.5-5.0について マッハ数のばらつきは土0.3\%である ${ }^{22}$.

Fig. 3 はこの衝撃波管の測定部に傾き角 52 度のくさ びを取り付けFig. 1 の光学系を用いて撮影した，アルゴ ンで初期圧 $14 \mathrm{kPa}$ と $28 \mathrm{kPa}$, マッハ数 2.8 の衝撃波の 反射を示す無限縞干涉写真である到。 なお，アルゴンで は，このくさび傾き角はこのマッハ数での遷移臨界角に 近い.

Fig. 3 で二回の露光間隔は $300 \mu \mathrm{s}$ なので, それぞれの 瞬間での衝撃波が重なって記録され，二重露光ホログラ フィー干渉写真となっている. 干渉縞は等密度線に对応 する. Fig. 3(a)，(b)では，くさび先端近くの反射形態は 正常反射を示し，一方，時間経過後の反射形態はマッハ 反射となっていること，また，初期圧の違いで現れる干 渉縞の数が異なることがよく分かる.

従来, くさびを過ぎる衝撃波の反射形態は自己相似と 
されたが, Fig. 3 に見るように，この仮定は必ずしも成 り立たないことが実証された. Henderson ら ${ }^{14)}$ は，アル

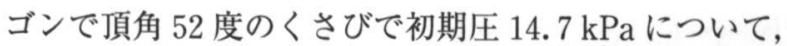
マッ八数 2.83 の衝撃波の反射を非常に精密に数值模擬 してくさびの先端では正常反射が現れ, ある遅れ距離を 経てマッハ反射が現れることを始めて示した．この数值 予測は明らかに反射衝撃波はいつも自己相似とはならず, その原因に衝撃波背後でくさび壁面に沿って成長する境 界層が支配的になることを示し, 同時に, 従来知られて いる実験結果と解析解の食い違いの原因を合理的に説明 している.

Fig. 3 は, その数值解を実証する目的で初期圧 14.7 $\mathrm{kPa}$ で, 衝撃波の到達位置を変えて無限縞干涉計写真を 繰り返し撮影した結果の一部である. 衝撃波三重点の軌 跡を実験と数值解で比較した結果を Fig. 4 に示す. 白丸 は数值解, 黒印は様々の初期圧での実験結果で, 数値解 と同じ初期圧での実験結果黒丸は僅かに食い違うが三重 点が成長の傾きはよく一致することが分かる.

再現性の良い衝撃波管を使って同じ初期条件で時系列

(a)

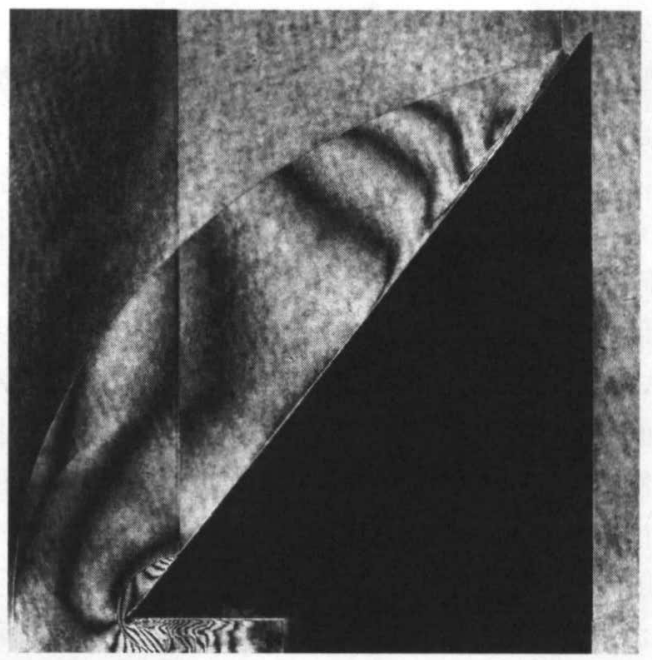

(b)

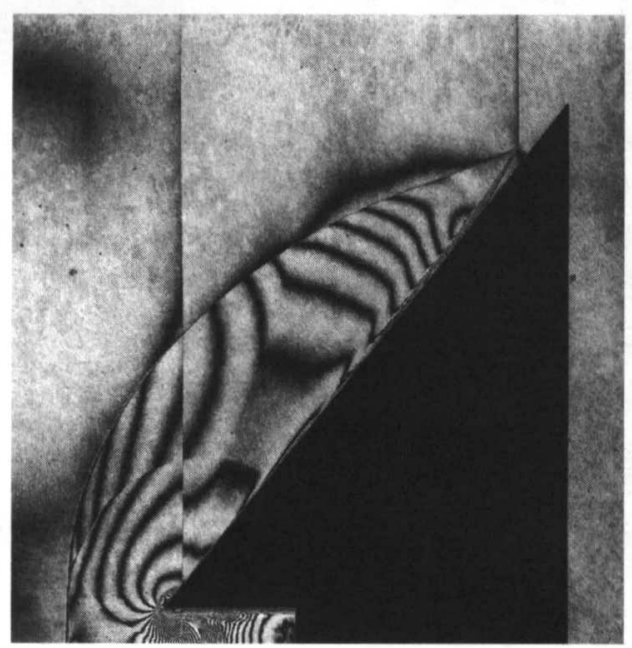

Fig. 3 Shock Wave Reflection over a 52 Degree Wedge at $\mathrm{Ms}=2.8$ in Argon : (a)Initial Pressure $14 \mathrm{kPa}$; (b) $28 \mathrm{kPa}$
的に繰り返して撮影した二重露光ホログラフィー干渉計 写真をコンピューターに取り込んで再配列し, 毎秒 24 コマ程度の龅速度で動画表示することができる. 高速度 写真の画像の空間解像は必ずしも高くないので, 高解像 度の干渉計写真は動画表示は現象の細部の変化を観察す ることができる.この動画表示は従来見逃していた衝撃 波の詳細な動的挙動を理解することができる。この動画 表示を数值シミュレーションのアニメーションと比較す れば, 数值解の精度を動的に検証することができる ${ }^{16}$.

\section{2 デトネーション波の初生}

可燃混合気の中で点爆発が起こると, 爆燃が起こりそ の前面に衝撃波が駆動される，その後，反応面は加速さ れて衝撃波面に追いついて, 衝撃波はデトネーション波 に移行する場合 (deflagration-to-detonation transition, DDT）があることが知られている．DDT に関する多く の実験があり, 可燃混合気の中でデトネーションを誘起 できる最小エネルギーを求める理論などもあるが, DDT の機序を普遍的に解明するには至っていない．また，デ トネーション管の実験では衝撃波背後で壁に沿って形成 される境界層は混合層なので, 境界層に沿って爆燃波が 加速されることも知られている.

したがって, DDT の研究では, 壁のない実験が必要 で比較的広い空間内で点爆発で誘起される衝撃波がデト ネーション波に遷移する過程を調べることに意義がある. Fig. 5 にその実験装置と光学系を示す ${ }^{17}$.

装置は壁厚さ $30 \mathrm{~mm}$, 直径 $290 \mathrm{~mm}$, 有効幅 $290 \mathrm{~mm}$ の鋼製の円筒容器で両端に厚さ $25 \mathrm{~mm}$ のアクリル樹脂 空が取り付けられている. 理論当量比の酸水素を分圧比 で充たし $30-100 \mathrm{kPa}$ とする. 容器の中心に吊した直径 約 $0.1 \mathrm{~mm}$ の木綿糸, 後に直径 $0.02 \mathrm{~mm}$ の銅線に, 微 小爆薬アジ化銀粒子 $3-10 \mathrm{mg}$ を貼りつけて, パルスヤ

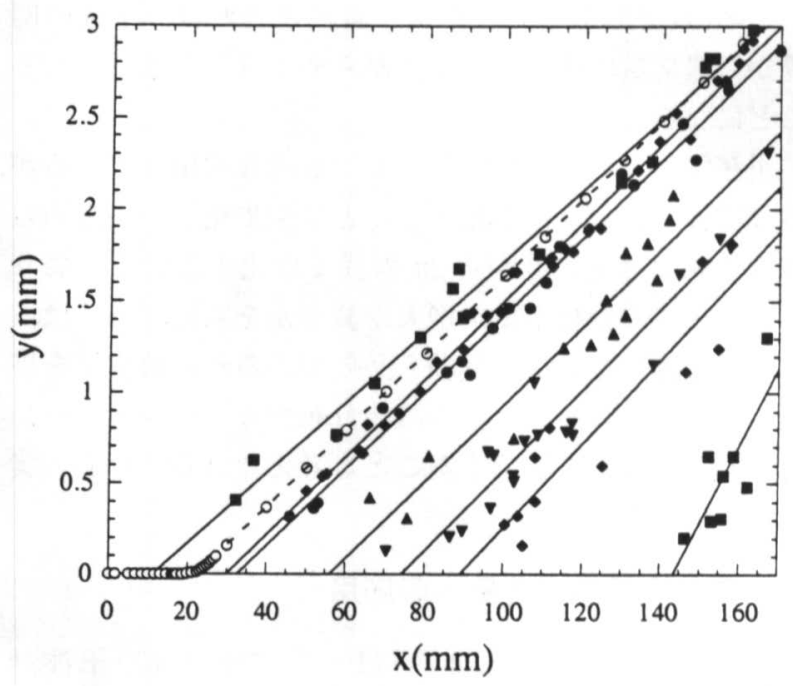

Fig. 4 Trajectories of Triple Points: Open Circle, Numerical Results at $14 \mathrm{kPa}$; Filled Symbols, at Various Initial Pressures, Filled Circle at $14 \mathrm{kPa}$ 
グレーザー光, パルス幅 $7 \mathrm{ns,} \mathrm{エネルギー} 20 \mathrm{~mJ}$ を照 射すると, 爆薬は瞬間的に起爆して混合気中に爆燃波を 作り衝撃波を駆動する. 爆燃波の速度は初期圧によって 変わるがほほ一定速度で然え広がるので, 衝撃波もほほ 一定速度で駆動される. しかし, 爆燃波が局所的に加速 されて衝撃波面に追いついたところから DDT が始まる ので, DDT は基本的に多次元現象である.

同じ初期条件で写真撮影の時期を変えた時系列的な観 察では, 衝撃波面は局所的にデトネーション波に遷移し， 波面全体の平均速度は爆燃波駆動の衝撃波速度から Chapman-Jouget デトネーション波速度 ${ }^{18}$ に漸近的に移 行する. Fig. 6 は, 爆薬量 $10 \mathrm{mg}$, 初期圧 $100 \mathrm{kPa}$ での 時系列的な二重露光ホログラフィー干涉計写真である.

写真から明らかなように, レーザー起爆したアジ化銀 ペレットの表面から未燃焼の微粒子が超音速で飛散して いる. 微粒子の後流は混合層を形成し, 後流に沿って爆 燃波面が加速されていることが分かる. 爆燃波が混合層 に沿って加速される現象の詳細な実験は進行中なので, ここでは, ホログラフィー干渉計法がこの種の複雑な流 れの構造を詳細に知る有効な手段であることを示した.

\section{3 極超音速流れの計測}

来世紀の前半に打ち上げを予定している日本のスペー スシャトル HOPE-X の大気圈再突入では, 宇宙機を空 力加熱から護る熱防設計が重要な開発研究課題になって いる. 航空宇宙研究所角田宇宙推進技術開発センターは, 世界最大の大きさと特性を誇る高温衝撃風洞を完成して 本格的な運用に着手し, 宇宙機の熱防御設計のデー夕取 得を開始した. 大気圈再突入の空気力学を風洞で模擬す る研究である. そのために, 風洞流れのマッハ数ばかり でなくてレイノルズ数をも実際の流れに一致するように， 相似パラメーター, 密度と装置の代表長さの積（binary parameter）を一致させなければならない. 風洞実験で は実際の宇宙機の数十分の一から数百分の一縮尺模型を 使うので, 風洞の気流流れ密度は実際の密度の数十倍か ら数百倍になり, 衝撃波風洞の淀み点状態は非常に高圧

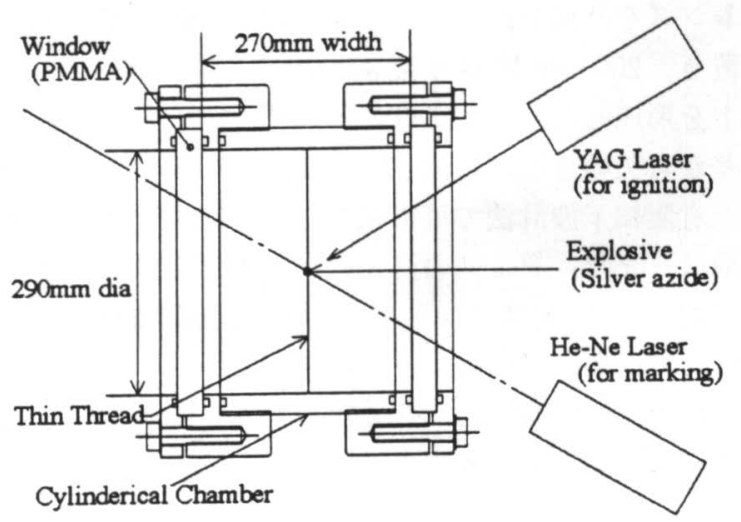

Fig. 5 Experimental Setup of Point Explosion of Silver Azide Pellet in Stoichiometric Oxy/hydrogen Mixture
高温になるのはやむを得ない ${ }^{19)}$.

東北大学流体科学研究所衝撃波研究センターでは, 航 空技術研究所との共同研究で小型の自由ピストン衝撃波 風洞を建設して, 最適ピストン作動法 (Tuned operation) の開発と確立に協力してきた. 最適ピストン作動法は経 験を通じて設計されてきた自由ピストン衝撃波風洞の特 性を, 気体力学の理論を基礎に合理的に集大成したもの である. Itoh ${ }^{20)}$ はこれを定式化して, 航空宇宙研究所の 大型高温衝撃風洞 (High Enthalpy Shock Tunnel, HIEST）の設計と製作に成功している.この装置は性能試 験を終えて設計性能と良く一致する実性能を示している.

Fig. 7 は東北大学流体科学研究所の小型自由ピストン

(a)
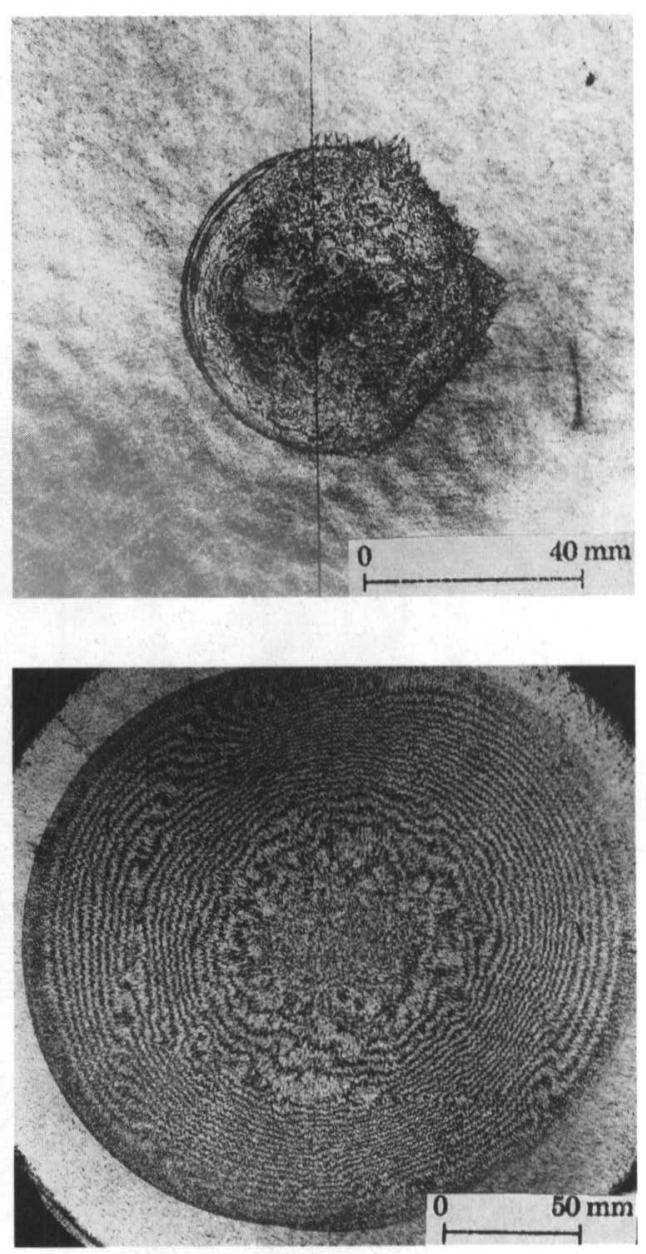

(b)

Fig. 6 DDT Incuded by Explosion of $10 \mathrm{mg}$ (15 J) Silver Azide Pellet of in Stoichiometric Oxy/hydrogen Mixture at $100 \mathrm{kPa}$ : (a)5 microsec after inginiton ; (b) 40 microsec

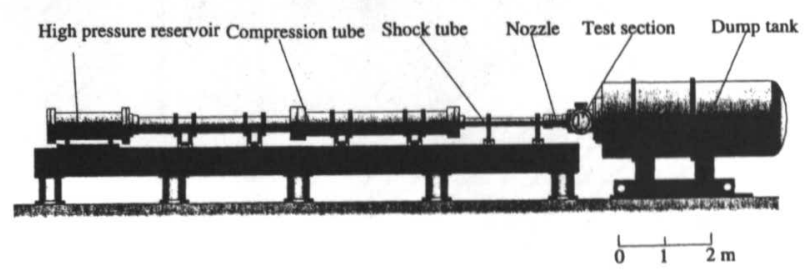

Fig. 7 Hypersonic Free Piston Shock Tunnel 
衝撃波風洞の概略図である. 70 リッターの高圧貯気槽 の空気で $3.1 \mathrm{~kg}$ のピストンを長さ $6 \mathrm{~m}$, 内径 $100 \mathrm{~mm}$ の圧縮管に沿って動かし，その中のへリウムを圧縮する. 圧縮された高温高圧へリウムは衝撃波管の高圧駆動気体 となって, 内径 $38 \mathrm{~mm}$, 長さ $2 \mathrm{~m}$ の衝撃波管の空気中 に強い衝撃波を発生する. 衝撃波は末端壁で反射して高 温高圧の淀み点状態を形成する．末端壁で淀み点状態が 比較的長く持続するように, 反射衝撃波と接触領域背後 の音響インピーダンスを一致させる Tayloring 条件が充 たされるように, 衝撃波管の初期条件が決められてい $ろ^{21)}$. その結果, この装置では最高淀み点エンタルピー $15 \mathrm{MJ} / \mathrm{kg}$ が達成できる.

衝撃波管末端壁はマイラー隔膜を介して円錐ノズル， 喉部直径 $7 \mathrm{~mm}$, 出口直径 $130 \mathrm{~mm}$, が接続されている. 円錐ノズルを通過して流れは膨張して, ノズル出口でや や拡がる速度分布を持つ極超音速流れとなる.ノズル出 口の気流のピトー圧測定から, 直径 $100 \mathrm{~mm}$ の一様流が 観察される. Fig. 8 に有限縞干渉計写真を示す : (a)幅 60

(a)

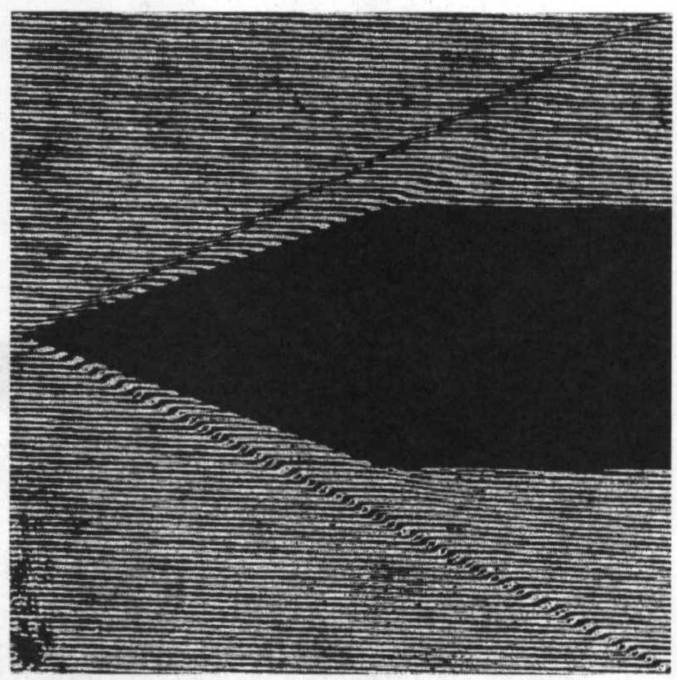

(b)

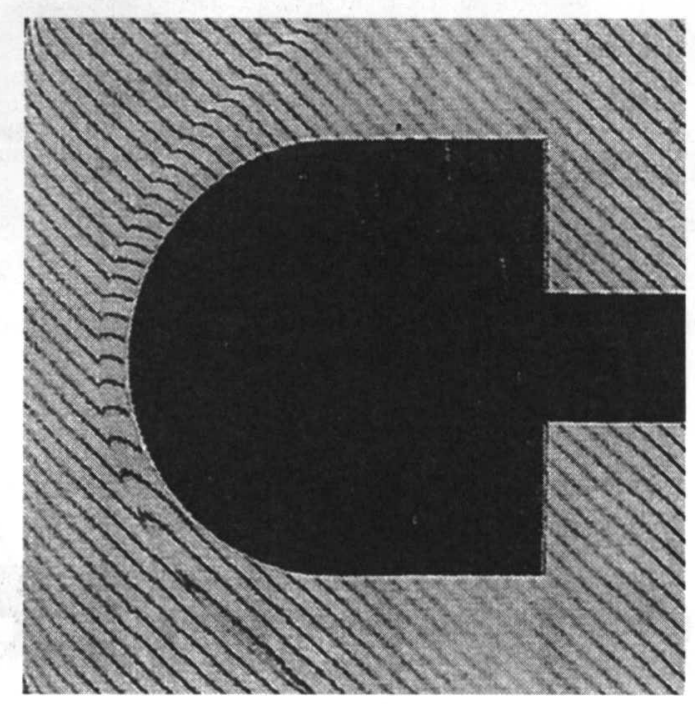

Fig. 8 Hypersonic Flows over : (a) a Wedge ; (b) a Hemispherical Cylinder $\mathrm{mm}$, 厚さ $15 \mathrm{~mm}$, 半頂角 20 度のくさび ; (b)直径 $50 \mathrm{~mm}$ の半球を先頭形状とする円筒. 流速, 密度, 圧力, 温度 はそれぞれ $2.75 \mathrm{~km} / \mathrm{s}$, 密度 $0.02 \mathrm{~kg} / \mathrm{m} \mathrm{3}, 2.26 \mathrm{kPa}$ お

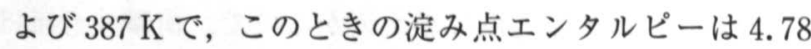
$\mathrm{MJ} / \mathrm{kg}$ であった ${ }^{8)}$.

このとき, 試験空気は部分的に解離していて, その成 分は平衡状態を仮定すれば：窒素分子 $66.69 \%$, 酸素分 子 $12.94 \%$ ，アルゴン $1.29 \%$, 酸素原子 $0.12 \%$ ，一酸 化窒素 $18.94 \%$ である. なお. このような混合気体の屈 折率と密度の関係はそれぞれの成分の屈折率のモル分率 の和で表される2).

有限干渉縞の方向はくさびでは流れ方向に平行に，ま た, 半球ではやや斜め方向に現れる. 干涉縞の変位を 2.3 節で述べたフーリエ縞解析法で処理して物体まわり の密度分布を求め, 結果を Fig. 9 に示す. なお, 半球で は軸対称流れなので, 前述の縞解析法で処理して得た位 相角の分布にアーベル変換を施して軸対称の密度分布を 得ている.この結果を数值計算の結果と対比すれば, 非 常によい一致が得られた.

\section{4 飛行する矢のまわりの流れ}

和弓はスポーツというよりは求道の要素を持ち, その 矢の飛行は非常に複雑な加速運動と連成されていて, 興 味ある研究課題である. 一方, その可視化は限られた範 囲にとどまっている, 佐藤 ${ }^{22}$. また, 矢の飛行速度は高々 数十 $\mathrm{m} / \mathrm{s}$ 程度なので圧縮性を示すには遅く, 衝撃波の 可視化に有効な方法は適用できない.この実験では, 矢 を液体窒素中に漬けて表面温度を十分下げて, 温度差を マーカーに人為的に温度境界層を作り, 矢の飛行を可視 化しようとする.

Fig. 10 は実験の配置を示す. 床面から約 $1.1 \mathrm{~m}$ の高 さに巻き㩰を置いて, $4.2 \mathrm{~m}$ の位置から片膝ついた姿勢 で矢を水平に射る. 実験室を薄暗くし, 卷蒠の中心を半 導体レーザー光で照射し目標とした. 矢は弓弦を放れた 直後から定常速度に達し, 卷䕗に当たるまで一定速度で 飛行すると考え, 弓から $2.2 \mathrm{~m}$ 離れた位置に二枚の焦 点距離 $300 \mathrm{~mm}$, 幅 $60 \mathrm{~mm}$, 長さ $300 \mathrm{~mm}$ の平凸の円筒 レンズを凸面を向き合わせて $500 \mathrm{~mm}$ 離して水平位置に 置き, $200 \mathrm{~mm}$ 間隔の幅 $50 \mathrm{~mm}$ の二組のレーザーシー トを形成した．矢が二枚のレーザーシートを横切る時間 差から矢の平均速度 $49.7 \pm 0.3 \mathrm{~m} / \mathrm{s}$ を得た.

有限縞干渉計法で可視化し, 第一回の露光は矢を射る 前に, また, 第二回の露光は矢が測定部に達したときに 同期させた. 矢はアルミニウム製で直径 $6 \mathrm{~mm}$, 長さ 1200 $\mathrm{mm}$ で先端にアルミニウムの鏃が付いている．矢の先端 $300 \mathrm{~mm}$ を液体窒素, 沸点 $77.2 \mathrm{~K}$, を満たしたジュワ瓶 の中に, 第二回露光の直前まで約 5 分間浸し, 矢をジュ ワ瓶から取り出して 15 秒から 30 秒の間につがえて射た. また,この間に矢の表面温度の回復は, 予備実験によっ て検定し, 約 $190-260 \mathrm{~K}$ を得た. 回復時間は矢を射る までの時間経過によって異なり, Fig. 11 では約 $260 \mathrm{~K}$ 

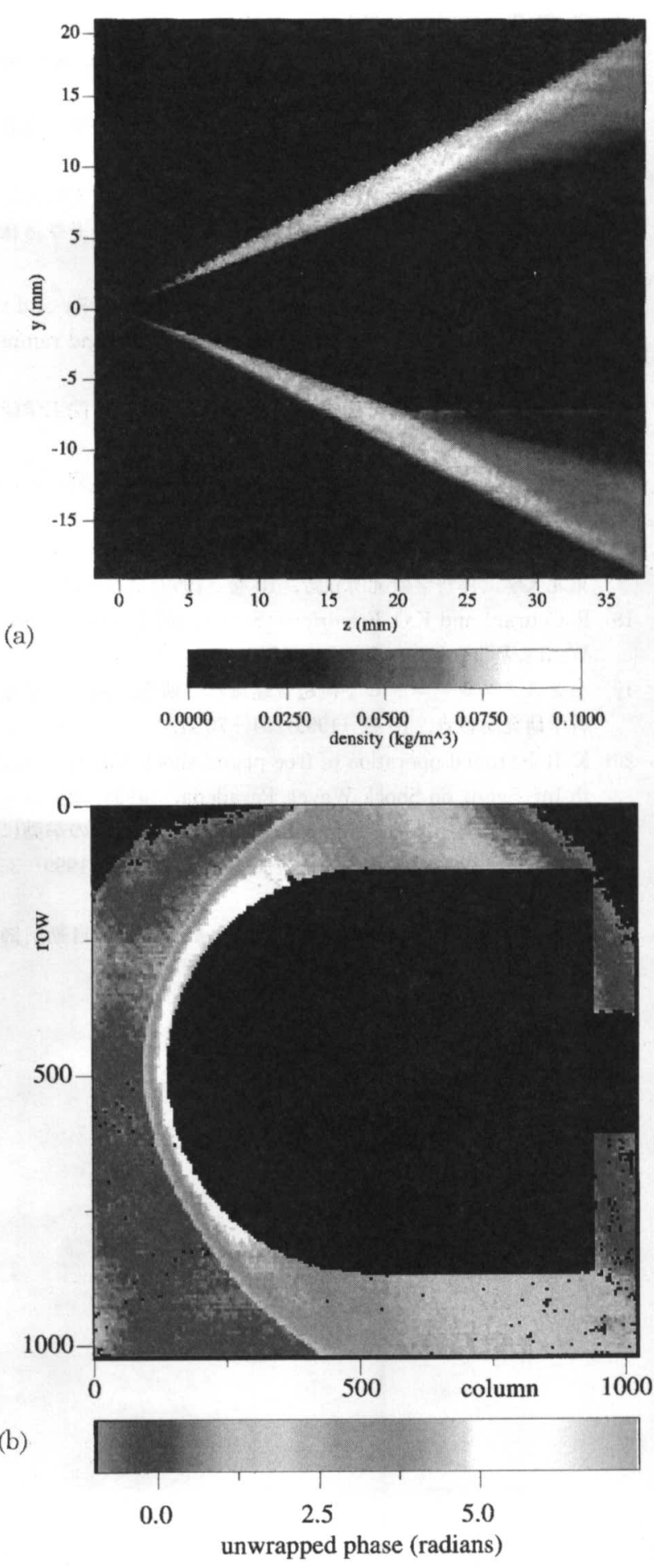

Fig. 9 Color Display of Density Distribution over Bodies shown in Fig. 8

であった。

Fig. 11(a)は有限干渉縞写真，Fig. 11(b)はそれをフーリ 工縞解析して得た位相角分布をアーベル変換して求めた 密度分布を示す. Fig. 11(a)より，矢の上面と下面で縞分 布は非対称であるが，これは矢の上下で対流の影響で温 度境界層の発達が異なるためと考えられる，また，標準 状態の空気について, 矢の直径を代表長さとするレイノ ルズ数は 21,900 なので, 矢の先端では層流境界層が発 達し, 先端からおおよそ $128 \mathrm{~mm}$ の位置で乱流遷移する

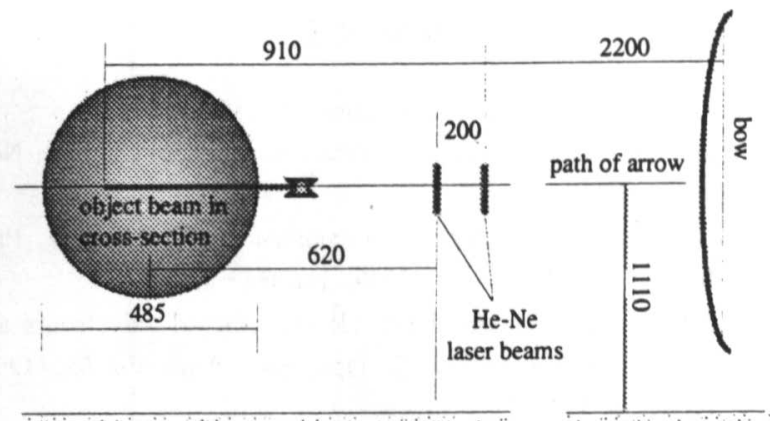

Fig. 10 Experimental Setup of Visualization of a Moving Arrow

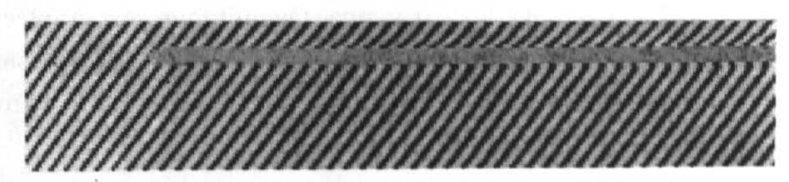

(a)
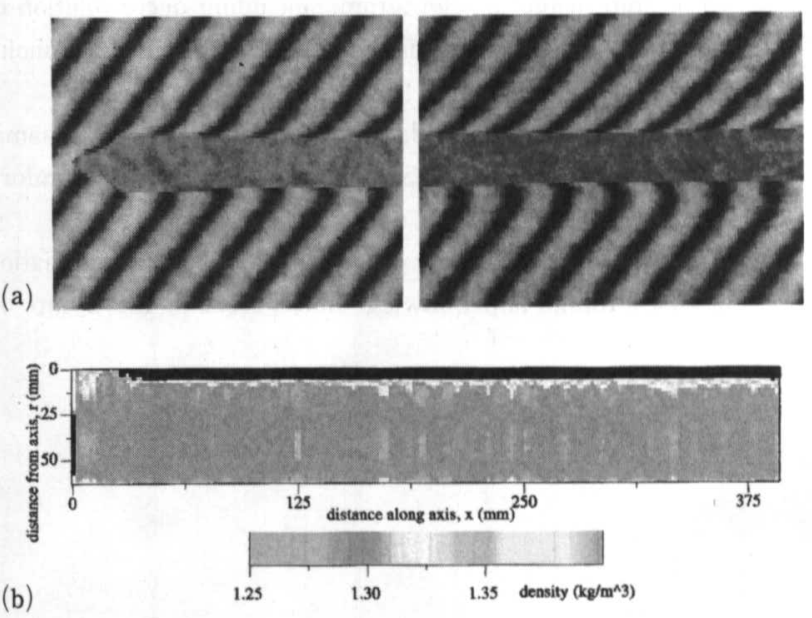

Fig. 11 Finite Fringe Interferogram over Thermal Boundary Layer over a Moving Arrow (a) and its Color Dispay of Density Distribution (b)

ことになるが，実際には鏃部分で既に境界層は乱流に遷 移している. 今後, 矢柄全体を冷やして, 矢全体の温度 境界層を計測して，これをマーカーとして矢に働く流体 力を推定することを計画中である.

\section{4. 結論}

現在, 数值シミュレーション法の発達と, 衝撃波管の 再現性が非常に向上したと言う技術発展の支援を受けて, 非定常の高速気流の可視化計測は「何かが写っている」 というと言う段階を超えて, 流れを定量的に計測して物 理を論ずる時代に到達した.この目的に, ホログラフィー 干渉計法が非定常の高速流れ計測の有効な手段になり, また,この方法を精緻な画像処理法と組み合わせて定量 的な計測ができる一例を示した. 特に, ここに示した事 例が, この研究分野に関心を持つ院生 - 若手の研究者諸 氏の参考になることを願いまとめとする. 


\section{参考文献}

1 ) J.M. Dewey, Private Communication (1998)

2) W. Mertzkirch: Flow Visualization, Academic Press New York (1974)

3 ) D. Gabor: Microscopy by reconstructed wavefronts, Proc Roy Soc London Ser A (1949) pp. 454-487

4) N.E. Leith and J. Upatinieks : Reconstructed wavefronts and communication theory, J. Opt. Soc. Am., Vol. 52, (1962) pp. $1123-1130$.

5 ) K. Takayama : Application of Holographic Interferometry to Shock Wave Research. Proc. SPIE. Vol. 398, (1983) pp. 174180

6）高山，渡邀：凹面を過ぎる衝撃波の回折（二重露光ホログラ フィー干渉計による観察)。速研報告, 45 巻（1980）33-63 頁

7) H. Babinski and K. Takayama:Quantitative holographic interferometry of shock wave flows using Fourier transform ringe analysis, Proc. 20 th Int Symp. on Shock Waves. Pasadena, (1995) pp. 1599-1604

8 ) F. Houwing and K. Takayama: Automated interactive analysis of finite frnge interferograms, including deconvolution of data from axisymmetric flows, Rep Inst Fluid Sci. Tohoku Univ. Vol. 11, (1999) pp. 95-121

9 ) G. Wortberg: A holographic interferomtry for gas dynamic research, Proc. 9 th Int. Symp. on Shock Tubes, Stanford Univ. (1974) pp.267-276

10) D. Russell et al. : Double expansion nozzle for recombination in shock tunnel and Ludwieg tube, Proc. 9 th Int. Symp. on
Shock Tubes, Stanford Univ. (1974) pp. 238-249

11) G. Ben-Dor: Shock Wave Reflection Phenomena, Sprringer Verlag, New York, (1992)

12）楊：弱い衝撃波の挙動に関する実験的・理論的研究，東北大 学大学院工学研筑科博士論文, (1995)

13）水戸部, 高山：〈さびおよび円錐を過ぎる衝揧波反射の正常 反射とマッハ反射の遷移暑れに関する研究, 東北大学流体科 学研究所報告, 10 巻 - (1999) 1-15 頁

14) L.F. Henderson et al : The effect of heat conductivity and viscosity of argon on shock wave diffracting over rigid ramps. J. Fluid Mech., Vol. 33 (1997) pp. 1-49

15）板橋：衝撃波の反射に関する研究, 東北大学大学院工学研究 科修士論文，(1998）

16）阿部, 高山：円筒配列と衝撃波の干涉に関する研究, 東北大 学流体科学研究所報告, 10 卷 (1999) 109-129 頁

17）小松ら：球状デトネーション波の伝播と発生に関する研究, 東北大学流体科学研究所報告, 10 巻（1999）131-145 頁

18) R. Courant and K.O. Friedrichs : Supersonic Flows and Shock Waves, Wiley Interscience, (1948)

19）ハンス・グレーニッヒ：極超音速流れの研究, 東北大学流体 科学研究所報告, 10 巻 (1999) 51-70 頁

20) K. Itoh : tuned operation of free piston shock tunnel, Proc. 20 th Int. Symp. on Shock Waves, Pasadena, (1995) pp. 21-29

21）是本ら：速度干涉計を用いた圧縮管内のピストンの挙動に関 する研究, 東北大学流体科学研究所報告, 10 巻（1999）3550 頁

22）佐藤, 高山：矢の飛行の計測，計測と制御，計測自動制御学 会誌，38 卷，（1999）266-261 頁. 

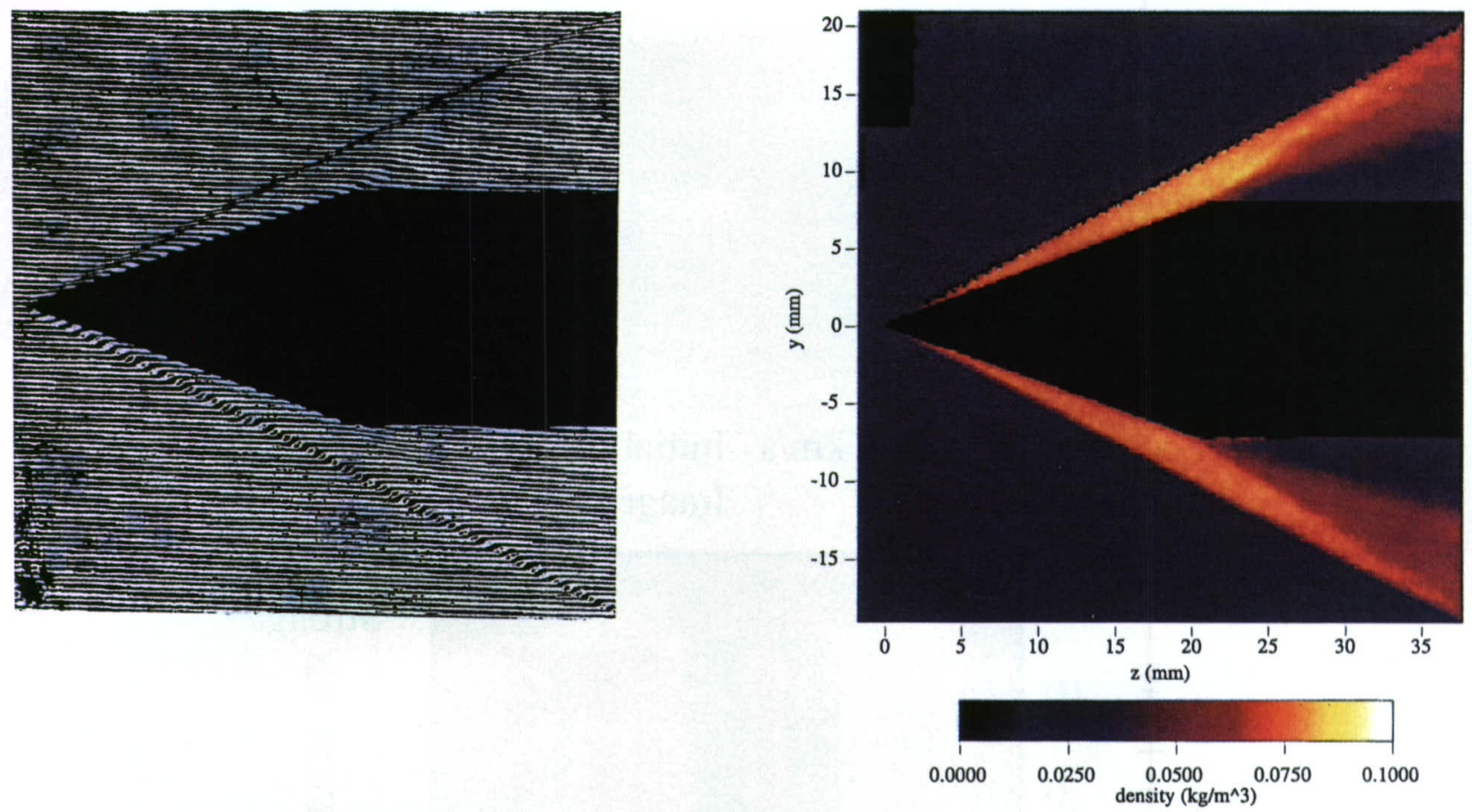

(a)
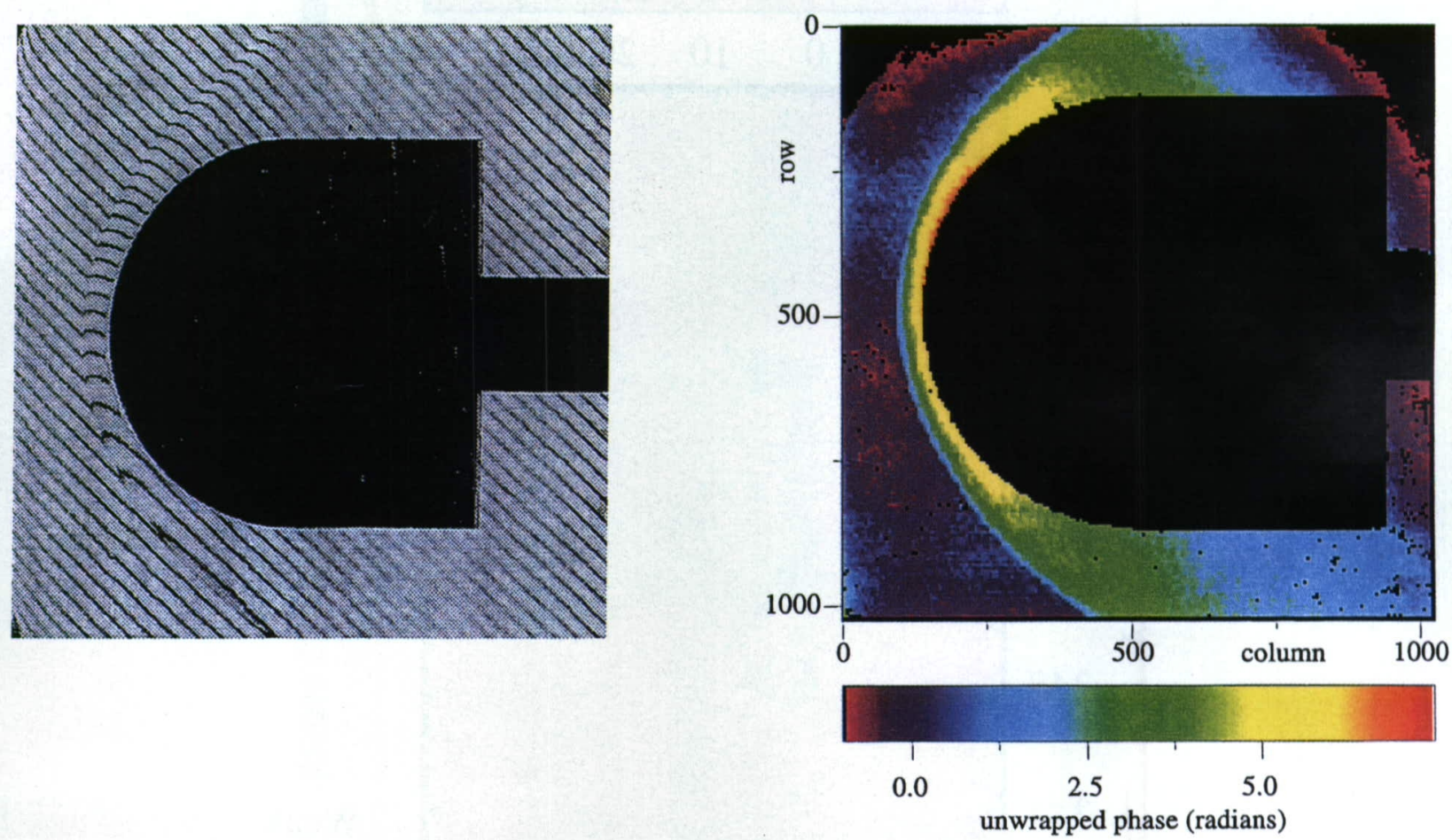

(b)

口絵 7 極超音速流れ中のくさび(a)および半球形状物体(b)まわりの衝擊波と背後流れ 